\title{
THE INNOVATION SYSTEM OF A TOURIST ENTERPRISE - A MODEL APPROACH
}

\author{
MAŁGORZATA JANUSZEWSKA, ${ }^{1}$ DARIA E. JAREMEN ${ }^{2}$ ELŻBIETA NAWROCKA ${ }^{3}$ \\ Wrocław University of Economics, POLAND \\ ${ }^{1}$ e-mail: mjanuszewska11@wp.pl \\ 2 e-mail: daria.jaremen@ue.wroc.pl \\ ${ }^{3}$ e-mail: elzbieta.nawrocka@ue.wroc.pl
}

KEYWORDS | innovation model, tourist enterprise, innovation system of a tourist enterprise

ABSTRACT The objective of the paper attempting to construct a model of the tourist enterprise innovation system, which allows explaining the mechanism of innovation activities in tourism. The basic research method used is the subject literature analysis. The modelling is based on a descriptive method derived from the deduction method. The result of conducted research is a proposal of an innovation system for a tourist enterprise (ISTE). The presented paper is both a review and theoretical study.

\section{Introduction}

The world literature offers numerous studies covering the problem of innovations and their implementation in enterprises representing various branches. In the field of tourism an extensive input in understanding the essence of innovations and innovativeness has been made by e.g.: A.M. Hjalager, X. Decelle, M. Peters, B. Pikkemaat, P. Jones as well as S. Nordin and B. Svennson. In Poland the following authors conduct in-depth studies on the innovation problems in the area 
of tourism economy: M. Bednarczyk and her team, E. Szymańska, E. Panfiluk and also the research workers at the Department of Marketing and Tourism Economy Management of Wrocław University of Economics. The research on innovativeness of tourist enterprises is most frequently concentrated on innovation characteristics and types, its description, organization, innovation process effects, distinguishing differences between production and service oriented innovations, innovation strategy identification, its success factors, as well as the role of a client and company staff in the course of innovation processes. Much emphasis is placed on the spatial aspects related to innovations in tourism economy. The efforts to diagnose the functioning system of an innovative enterprise are undertaken less often. It happens so, because in most cases an innovation process is analyzed as the sequence of activities of a regulatory and real nature. Despite the above-mentioned examples of the conducted research and studies on tourism sector innovativeness, they still remain quite rare and hence the need for more. While trying to fill in this gap the authors attempted constructing model of the tourist enterprise innovation system, which is also the primary purpose of this article.

The theoretical background of systemic approach to innovation in economic science has been applied in e.g. the theory of innovation as interactive learning and economic theories of evolution. Interactive learning is based on experimenting in the process of knowledge production consisting in the division disappearance between those who "produce" it and those who undergo the process of learning. As a result an innovation process remains a learning process. On the other hand, in the case of the evolution oriented model for innovation creation process it is the solution to a specific problem which is analyzed and developed. New ideas, constituting its solution are of diverse quality. Some of them are based on old (reproduction) and others on better (selection) solutions. The directions of changes in presented ideas, i.e. the launched products are characterized by different competitiveness. New solutions are based on the existing ones in the sense that sales revenues from the old products finance the innovative ones. ${ }^{1}$

The basic research method, applied for the needs of the research problem analyzed in the presented article, is the subject literature review in search of the theoretical background explaining the problem of innovation, with particular emphasis on innovation in tourism and the results of research on enterprise innovativeness confirming the innovation theories described in the literature. The following assumptions have been adopted in the model construction process referring to an innovation system of a tourist enterprise: regarding a tourist enterprise model - an economic and organizational model of an enterprise has been selected, and in terms of an innovation model - the model of systems integration and networking is applied. The discussion also covers cooperation networks as an important dimension of innovation activity. The modelling is based on a descriptive method derived from the deduction method. The constructed model is of explanatory nature. The data necessary for model construction originate from secondary sources. As a result of the

${ }^{1}$ R. Galar, Gospodarka oparta na wiedzy i innowacje przełomowe, in: Gospodarka oparta na wiedzy - wyzwania dla Polski XXI wieku, ed. A. Kukliński, Warszawa 2001, p. 153. 
conducted research the proposal for an innovation system model of a tourist enterprise (ISTE) is presented.

\section{Innovation models - theoretical discussion}

The term "innovation" originates from Latin "innovates", i.e. renewal, creating something new. In Poland this concept is defined as "introducing something new, the newly introduced conception, a novelty, a reform.”2 The colloquial understanding of this word refers to something new and different form the existing solutions; it is associated with the need to introduce changes for better $^{3}$ and is very often used as the synonym of the word "change."

The subject literature emphasizes the problem of various definitions associated with the term "innovation", as well as freedom of its interpretation. ${ }^{4}$ The multitude of definitions referring to the innovation concept and the absence of the commonly accepted theories in this matter confirm that the research on this problem is still valid and indispensable, as well as expected.

In the 1990s two crucial transformations in the way of approaching innovation were observed. Firstly, the opinions were expressed that service-oriented innovations very often played an extremely important role in an innovation process (presented in its macroeconomic aspect), which changed, to an extent, the perception of service providing entities, including the ones representing tourism sector, as the recipients of innovations created by others. Secondly, the opportunities for innovation activities were recognized in other areas rather than technological ones only, which resulted in an increased importance of changes implemented by the service sector.

The service-oriented innovation can be understood as an effect of the change process, or the process itself, related to a product and characterized by high element of immateriality, the need for direct contact between a service provider and a customer, an integration of external factors combined with service heterogeneity, resulting from high personal contribution of the human factor. ${ }^{5}$

At the background of the existing definitions ${ }^{6}$ of innovations the researchers analyzing this problem take up adequate attempts to explain the mechanism of innovation construction in the form of models. These models are characterized in Tables 1 and 2. Generally, they are divided into linear models, also referred to as classical ones, and complex models (including e.g. integrated, open, coupled and distributed models).

2 Słownik wyrazów obcych, ed. J. Tokarski, PWN, Warszawa 1980, p. 307.

${ }^{3}$ W. Janasz, K. Kozioł, Determinanty działalności innowacyjnej przedsiębiorstw, PWE, Warszawa 2007 , p. 11.

${ }^{4}$ J. Penc, Innowacje i zmiany w firmie, Agencja Wydawnicza Placet, Warszawa 1999, p. 143.

${ }^{5}$ C. Küpper, Service Innovation - A Review of the State of the Art, Working Paper Series LMU, University of Munich, Institute for Innovation Research and Technology Management, Munich 2001, p. 19.

${ }^{6}$ The presented article does not provide the review of innovation definitions, since they are broadly discussed in many publications in the field of economics and management. 
Table 1. Review of linear innovation models

\begin{tabular}{|c|c|c|}
\hline Model type & Model characteristics & $\begin{array}{c}\text { Leading } \\
\text { representatives }\end{array}$ \\
\hline Technology push model & $\begin{array}{l}\text { Starting point for changes is the development of science and technology, which allow } \\
\text { innovations. The role of the market is reduced to accepting, in advance, the changes } \\
\text { applied in products or processes. The approach is close to the neoclassical theory } \\
\text { of market failure, primary research is the driving force of innovations, while the role } \\
\text { of the market is passive }\end{array}$ & $\begin{array}{l}\text { Ch. Freeman, } \\
\text { J. Ronayne }\end{array}$ \\
\hline Demand pull model & $\begin{array}{l}\text { Innovation is the reaction to the size and structure of demand, the development } \\
\text { of marketing and quality management concept. Market plays an active role, whereas } \\
\text { knowledge is a passive factor }\end{array}$ & $\begin{array}{l}\text { J. Schmookler, } \\
\text { R.L. Daft, } \\
\text { R. Williams, } \\
\text { D. Edge, } \\
\text { P. McGowan }\end{array}$ \\
\hline Demand-supply model & $\begin{array}{l}\text { Emphasizes feedback between the particular stages of innovation process and also } \\
\text { interactions between market, science and enterprise. Models focus on the role } \\
\text { of knowledge and enterprise resources. Combining technical possibilities } \\
\text { of an enterprise and market needs remains the essence of this process }\end{array}$ & $\begin{array}{l}\text { S.J. Kline, } \\
\text { N. Rosenberg, } \\
\text { C. Wessner, } \\
\text { R. Rothwell, } \\
\text { W. Zegveld }\end{array}$ \\
\hline
\end{tabular}

Source: authors' compilation based on: M.S. Lewandowska, Innowacje otwarte polskich przedsiębiorstw, „Gospodarka Narodowa” 2014, nr 2, pp. 53-80; J. Perenc, J. Hołub-Iwan, Innowacje w rozwoju konkurencyjności firm, Wydawnictwo C.H. Beck, Warszawa 2011, pp. 55-57; J. Czerniak, Polityka innowacyjna w Polsce, analiza i proponowane kierunki zmian, Difin Warszawa 2013, pp. 20-29; A.H. Jasiński, R. Ciborowski, Ekonomika i zarządzanie innowacjami, Wydawnictwo Uniwersytetu w Białymstoku, Białystok 2012, pp. 49-57; E. Szymańska, Procesy innowacyjne przedsiębiorstw świadczacych ustugi w zakresie organizacji imprez turystycznych, Oficyna Wydawnicza Politechniki Białostockiej, Białystok 2013, pp. 70-85; A.H. Jasiński, Innowacyjność w gospodarce Polski, modele, bariery, instrumenty wsparcia, Wydawnictwo Naukowe Wydziału Zarządzania Uniwersytetu Warszawskiego, Warszawa 2014, p. 16; S. Waresa, Systemy innowacyjne we wspótczesnej gospodarce światowej, Wydawnictwo Naukowe PWN, Warszawa 2012, pp. 35-38.

Table 2. Review of complex innovation models

\begin{tabular}{|c|c|c|}
\hline Model type & Model characteristics & $\begin{array}{c}\text { Leading } \\
\text { representatives }\end{array}$ \\
\hline 1 & 2 & 3 \\
\hline Integrated model & $\begin{array}{l}\text { At least two integrated subsystems operate accordingly. Innovations result from } \\
\text { sequential exchange of information between marketing, production and R\&D } \\
\text { specialists. They are based on interfunctional organization and team work and also } \\
\text { company staff creativity. Its purpose is the optimization of internal innovation } \\
\text { processes in an enterprise }\end{array}$ & H.K. Tang \\
\hline Open model & $\begin{array}{l}\text { Innovation activities based on the concept of knowledge management.Innovation } \\
\text { processes implemented in cooperation with different business environment. It is } \\
\text { crucial to protect intellectual property. The following principle should be listed in } \\
\text { terms of open innovations: } \\
\text { - a company is not able to employ the best specialists, thus it searches for partners } \\
\text { in its environment, } \\
\text { - external research and development work is crucial, } \\
\text { - an enterprise does not have to initiate research works to benefit from them, } \\
\text { a success can be achieved through combining internal and external ideas, } \\
\text { - constructing an effective business model is more important than being the first }\end{array}$ & $\begin{array}{l}\text { H. Chesbrough, } \\
\text { S.J.H. Graham, } \\
\text { D.C. Mowery }\end{array}$ \\
\hline
\end{tabular}




\begin{tabular}{|c|c|c|}
\hline 1 & 2 & 3 \\
\hline $\begin{array}{l}\text { Model of systems } \\
\text { integration } \\
\text { and networking }\end{array}$ & $\begin{array}{l}\text { Market factors and higher customers' awareness play the crucial role } \\
\text { in an innovation process. Innovation models are constructed in the form of } \\
\text { a network (networking). Establishing networks is easier owing to ICT and the } \\
\text { Internet. Network management resembles simultaneous management of numerous } \\
\text { businesses through a continuous search for the possibilities of the most favorable } \\
\text { allocation of innovation potential components. The development of management } \\
\text { systems and the increasing number of horizontal and vertical agreements remain } \\
\text { the reasons for model construction }\end{array}$ & R. Rothwell \\
\hline $\begin{array}{l}\text { Distributed innovation } \\
\text { model }\end{array}$ & $\begin{array}{l}\text { Model is concentrated on open innovation based on H. Chesbrough's proposal, } \\
\text { however, it criticizes confidence as the basis for open innovation success. The model } \\
\text { assumes more distributed leadership structure based on individuals presenting skills } \\
\text { in influencing others. It requires knowledge flow between various entities to open } \\
\text { opportunities for creating innovations }\end{array}$ & P. Hobcraft \\
\hline
\end{tabular}

Source: authors' compilation based on: M.S. Lewandowska, Innowacje otwarte polskich przedsiębiorstw, „Gospodarka Narodowa" nr 2, pp. 53-80; J. Perenc, J. Hołub-Iwan, Innowacje w rozwoju konkurencyjności firm, Wydawnictwo C.H. Beck, Warszawa 2011, pp. 55-57; J. Czerniak, Polityka innowacyjna w Polsce, analiza i proponowane kierunki zmian, Difin, Warszawa 2013, pp. 20-29; A.H. Jasiński, R. Ciborowski, Ekonomika i zarzadzanie innowacjami, Wydawnictwo Uniwersytetu w Białymstoku, Białystok 2012, pp. 49-57; Szymańska, 2013, pp. 70-85, A.H. Jasiński, Innowacyjność $w$ gospodarce Polski, modele, bariery, instrumenty wsparcia, Wydawnictwo Naukowe Wydziału Zarządzania Uniwersytetu Warszawskiego, Warszawa 2014, p. 16; S. Waresa, Systemy innowacyjne we współczesnej gospodarce światowej, Wydawnictwo Naukowe PWN, Warszawa 2012, pp. 35-38.

P. den Hertog, having considered the specific nature of service providing businesses, constructs five models covering innovative behaviors of service enterprises. They are distinguished in terms of innovation sources (Table 3). P. den Hertog's comments and observations can also be directly referred to tourist enterprises.

Table 3. Innovation models of service companies by P. den Hertog

\begin{tabular}{|c|c|c|}
\hline Model & Characteristics & Comments \\
\hline 1 & 2 & 3 \\
\hline Supplier-dominated innovation) & $\begin{array}{l}\text { Innovations in services are created based } \\
\text { on technological innovations offered by the } \\
\text { industry sector, launched at the market by } \\
\text { manufacturing companies }\end{array}$ & $\begin{array}{l}\text { The paradigm of industrial innovations is the } \\
\text { dominating one (service providing companies remain } \\
\text { the consumer of innovations and a passive component } \\
\text { of an innovation system). Such innovations have to be } \\
\text { modified quite often due to the differences between } \\
\text { production and service oriented innovations }\end{array}$ \\
\hline Innovation within services & $\begin{array}{l}\text { Innovation is initiated and implemented } \\
\text { by a service company itself and is related } \\
\text { to typical service functions, e.g. creating } \\
\text { a new product, a new package of services } \\
\text { or a distribution system }\end{array}$ & $\begin{array}{l}\text { Company intellectual capital and its internal } \\
\text { innovation activities are of crucial significance }\end{array}$ \\
\hline Client-led innovation & $\begin{array}{l}\text { A service company responds to the needs } \\
\text { expressed by clients }\end{array}$ & $\begin{array}{l}\text { Based on J. Schmookler's concept it can be stated } \\
\text { that an enterprise creates inventions as the reaction } \\
\text { to client's (consumer's) needs and imposed by a client } \\
\text { (consumer) }\end{array}$ \\
\hline Innovation trough services & $\begin{array}{l}\text { A service company generates innovations } \\
\text { introduced in a given service enterprise }\end{array}$ & $\begin{array}{l}\text { Referring to the concept of H. Chesbrough's open } \\
\text { innovations it can be stated that the diffusion } \\
\text { of innovations in service sector remains the primary } \\
\text { source of innovations in services }\end{array}$ \\
\hline
\end{tabular}




\begin{tabular}{cll}
\hline 1 & \multicolumn{1}{c}{2} & \multicolumn{1}{c}{3} \\
\hline Paradigmatic innovation & $\begin{array}{ll}\text { All entities connected with a particular } \\
\text { activity influence the development } \\
\text { and implementation of innovations } \\
\text { or are forced to assimilate them }\end{array}$ & $\begin{array}{l}\text { This model applies the concept of a coupled } \\
\text { system, where innovations are created as the effect } \\
\text { of globalization, computerization and human capital } \\
\text { development, they combine technical possibilities } \\
\text { of an enterprise and market needs }\end{array}$ \\
\hline
\end{tabular}

Source: authors' compilation based on: P. den Hertog, Knowledge-Intensive Business Services as Co-producers of Innovation, "International Journal of Innovation Management" 2000, Vol. 4, No. 4, pp. 491-528; J. Howells, Innovation and Services: New Conceptual Framework, CRIC Discussion Paper No. 38, August 2000, p. 5.

The above presented review of models has allowed for identifying the ones which best reflect the specific nature of innovation activities in tourism. Therefore, the following models have been considered: integrated systems and networking, open innovations by $\mathrm{H}$. Chesbrough and innovation sources in services P. den Hertog.

\section{Innovation system model of a tourist enterprise - the authors' proposal}

The systemic approach to the description of enterprise functioning in economic sciences gained the greatest popularity in the 1960s in the period of large, international, industrial organizations' management. At that time organizations presented the form of a social and technical centrally managed system. The system was understood as a linear input and output arrangement (the system had explicit boundaries against the supra-system - environment). In the 1980s, in the so-called school of organizational games, conflicts occurring in organizations and having impact on their functioning were noticed, whereas in the school of organizational balance an organization was observed as the system aimed at such balance against the interfering factors. A. Kołodziejczyk emphasizes that the most recent systemic approach in economic sciences is related to the school of established internal and inter-organizational networks. The systemic approach, applying the network concept, remains the theoretical background of the constructed integrated and networking models as the ones which best describe the processes occurring within them. The basic assumptions of the systemic approach became the conceptual basis for an innovation system model of a tourist enterprise (ISTE). This system does not operate in a vacuum, since it is influenced by the arrangement of many components in an enterprise. Therefore, in the conception phase of ISTE model construction it was necessary to select the model of an enterprise. The subject literature offers different models of an enterprise, among which the models broadly described by T. Gruszecki are listed, i.e. an economic model and an organizational model. In the case of an economic model the system is perceived in efficiency categories, which means the difference between resources (outlays) and their combination effect, whereas an organizational model presents an enterprise in such categories as e.g.: functions, strategies, values, structures, systems and information streams. These components have impact on innovation creation in a tourist enterprise. 
The model discussed in the article (Figure 1) is of interdisciplinary nature, most appropriate to describe complex phenomena occurring in the functioning of an enterprise, also including a tourist enterprise.

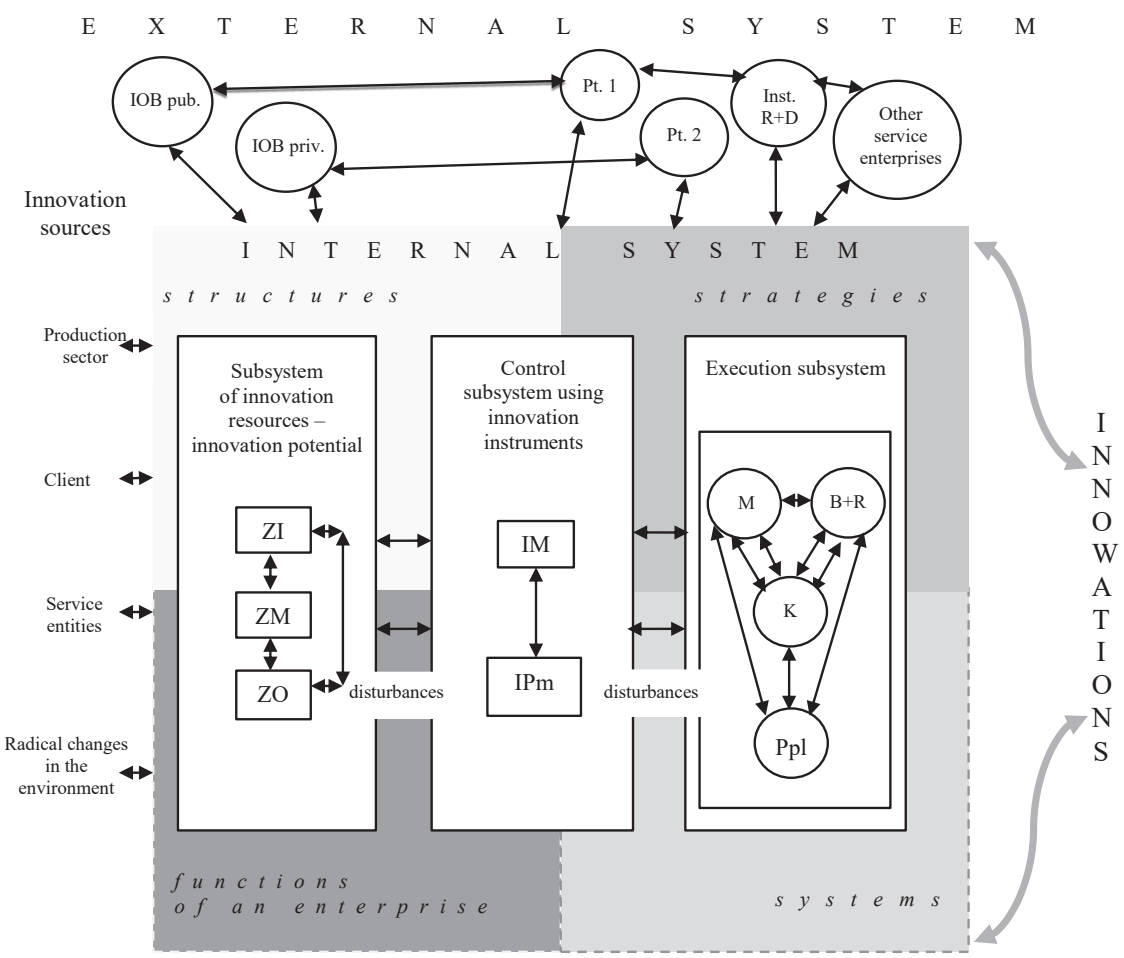

Explanatory notes:

ZI - subsystem of intellectual resources

$\mathrm{B}+\mathrm{R}$ - innovation specialists

$\mathrm{ZM}$ - subsystem of material resources

Ppl - front staff

$\mathrm{ZO}$ - subsystem of organizational resources

$\mathrm{K}$ - client

IM - subsystem of material instruments

IOB - business environment institutions

IPm - subsystem of non-material instruments

$\mathrm{Pt}$ - tourist enterprise

$\mathrm{M}$ - marketing staff

Inst. $\mathrm{B}+\mathrm{R}-\mathrm{R} \& \mathrm{D}$ units

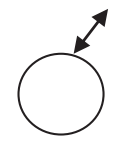

knot with relations

subsystem

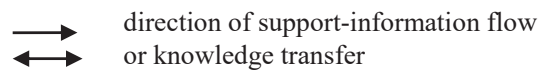

Figure 1. Suggested innovation system model of a tourist enterprise

Source: the authors' compilation. 
ISTE constitutes a set of components connected with each other by means of relations in the way which forms a unity capable of innovation activity. Mutually related systems, i.e. an internal and external one, were distinguished in it. The internal system is made up of the following subsystems: innovation resources (innovation potential), control (using innovative instruments) and execution system, while the external one consists of an institutional subsystem made up of the network of institutions in a public and/or private sector and their mutual interactions. ISTE covers organizational units and employees creating inter-functional teams in an internal system, as well as e.g. business environment institutions, universities, research centers, tourist enterprises and other economic entities, public authority entities - in an external system. The innovation-oriented activity of a tourist enterprise should be understood as the set of attitudes and activities in an execution sphere, but also in the sphere of innovation potential creation and development as well as innovation instruments' application and selection, resulting in networking stimulation in an interfunctional organization of a tourist enterprise, as a result of which an innovation (technological, organizational, marketing, social) is created. The innovation activity remains the effect of interactions with external system components. An innovation system creates a specific mechanism of relations between its elements and makes their impacts both complex and integrated.

The innovation potential of an enterprise (subsystem of innovation resources) can be interpreted as the arrangement of internal conditions and characteristics of a particular entity, which allows creating and developing innovations. It is made up of three subsystems, i.e. the subsystem of intellectual resources, the subsystem of material resources and the subsystem of organizational resources. The area of intellectual resources covers abilities, skills, knowledge, creativity presented by employees, and primarily their ability to establish a network, to absorb knowledge, its "anchorage" and distribution inside an innovation system. The subsystem of material resources includes e.g.: gastronomic equipment, buildings, constructions, in-room furnishings. The subsystem of organizational resources comprises e.g.: formal and informal organization of an enterprise, organizational structure, innovation strategy, service process organization. The research conducted by the team from University of Applied Sciences in Münster ${ }^{7}$ confirms that not all resources are equally important for an innovation process. Among the most important components of intellectual resources subsystem the following are included: employment strategy, diversification of internal resources and communication with the environment. With reference to the subsystem of organizational resources the authors have emphasized the role of: internal communication, management support and employees' motivation, whereas in case of material resources subsystem they distinguished: optimal financial resources and adequate equipment.

The innovative activity is stimulated by means of material and non-material instruments constituting basic elements of the control system. Based on the assumptions of management theory, they include: strategies, methods and models for innovation management. In accordance with the

${ }^{7}$ D.M. Leich, S. Gökduman, T. Baaken, Service Innovation, Project Report, University of Applied Sciences, Münster 2010, www.science-marketing.com. 
above-mentioned research, conducted by German experts, staff motivating methods remain the most important instrument.

The execution subsystem has been presented in the form of a network. Having considered the specific nature of tourist enterprises, attention should be paid to relations between R\&D and marketing personnel, and also front staff, who take the role of innovation co-creators. Based on P. den Hertog's conception, an opinion can be expressed that the role of a client at the contemporary tourism market has been evolving. A client is no longer a participant of a purchase-sale transaction, but takes the role of an active player and the subject influencing an enterprise offer by participating in creating innovations. The client's knowledge internalization and his/her participation in innovations' creation is possible as a result of introducing adequate conditions in the social environment of a tourist enterprise. Among the most important ones the following can be listed: combining tasks related to knowledge management, to marketing and customer service, to the implementation of customer relations management system, client's access to company knowledge by means of client coaching, lists and discussion forums, website allowing knowledge sharing with a client, company operations transparency, e.g. presenting threats related to the consumption of tourist services, online exchange of experiences and knowledge transfer harmonization in an enterprise, between an enterprise and clients as well as between company clients. ${ }^{8}$

Each system is subject to certain disturbances resulting in the higher risk and uncertainty in innovation activities carried out by an enterprise, which can be divided into disturbances in an internal or external system (Picture 1 presents internal system disturbances only). Based on the analyses conducted in service sector of the $\mathrm{EU}^{9}$ countries and microenterprises in Poland ${ }^{10}$, the first group covers mainly the following:

- insufficient financial means,

- high costs of innovation implementation,

- insufficient level of employees' qualifications and knowledge, unfavorable organizational structures,

- resistance to change among staff, reducing the tendency for innovation oriented behaviors.

Among the disturbances in an external system the following have to be listed:

- high level of risk resulting from innovation implementation,

- low demand for innovations, unfavorable policy carried out by the State and local authorities,

- innovation protection problems - easy to imitate.

Based on P. den Hertog's conception of innovation sources, their four external sources can be distinguished (i.e. production sector, client, service providing entities and radical changes in the environment) and also one internal source related to innovation potential. In practice not all

${ }^{8}$ C.K. Prahalad, V. Ramaswamy, Przyszłość konkurencji, PWE, Warszawa 2005; Kulturowe kadrowe problemy internacjonalizacji przedsiębiorstw, ed. P. Wachowiak, SGH, Warszawa 2008; Europejskie wymiary przedsiębiorczości, eds. H. Kruk, K. Skrzeszewska, Akademia Morska, Gdynia 2008, G. Probst, S. Raub, K. Romhardt, Zarządzanie wiedza w organizacji, Oficyna Ekonomiczna, Kraków 2002.

${ }^{9}$ Innowacje w zrównoważonym rozwoju organizacji, ed. W. Janasz, Difin, Warszawa 2011, p. 195.

${ }^{10}$ M. Juchniewicz, B. Grabowska, Innowacyjność mikro-przedsiębiorstw w Polsce, PARP, Warszawa 2010, p. 57. 
sources are equally important, which has been confirmed by numerous studies covering tourist enterprises. The authors' own research, performed in the period 2006-2010, is worth mentioning. The exploration covered the group of enterprises representing such branches as hospitality, gastronomy, spa industry and travel agencies. It should be emphasized that the results obtained are neither comparable nor representative, but they can serve as a good practical illustration to be used as an incentive for further, in-depth research on innovation sources of tourist enterprises. The research, conducted in 2006, has proved that the Internet, clients, professional journals and counterparties remain the primary innovation sources in tourist enterprises. ${ }^{11}$ On the other hand, the research conducted in 2008, in public spa enterprises, showed that professional experience of staff and managers, courses and trainings and also the Internet ${ }^{12}$ were the most important factors in an innovation process. The analyses performed in 2010, covering hospitality and gastronomy enterprises, allowed to distinguish: clients, owner's creativity, the Internet, employees and competitors as the main innovation sources. ${ }^{13}$ It can be generally stated that the sources in an innovation process are of both internal and external nature and mainly take the form of knowledge acquired by employees and managers, clients, competitors and counterparties, which remains in line with P. den Hertog's conception.

\section{Final remarks}

The discussed innovation system of a tourist enterprise is the authors' attempt of a research problem presentation due to the absence of comparative material originating from tourism sector (research in the area of innovation is dominated by production companies or high-tech sector institutions). Currently, the process-oriented approach is the dominating one in the innovation research, which in Polish subject literature is presented by e.g. E. Szymańska. ${ }^{14}$ The authors' approach emphasizes the systemic presentation revealing the complexity of innovation processes, their dependence on various factors and components of internal and external systems in a tourist enterprise. In accordance with the systems theory assumptions as well as different conceptions and approaches to innovation problems and their generation presented in the research environment, the suggested innovation system model of tourist enterprises remains the subsystem of a larger suprasystem, referred to as an external one, which is made up of many subsystems and functions in the environment of other systems in an organization (e.g. marketing, personnel, financial, etc. systems) and enters into various interactions with them. It is an open system, which cooperates with the

${ }^{11}$ K. Perechuda, E. Nawrocka, Zarządzanie informacja $i$ wiedza jako instrument uzyskiwania przewagi konkurencyjnej podmiotów gospodarki turystycznej, Ekonomiczne Problemy Turystyki nr 7, Zeszyty Naukowe Uniwersytetu Szczecińskiego nr 429, Szczecin 2006, pp. 237-244.

12 M. Januszewska, E. Nawrocka, Rola klienta $w$ działalności innowacyjnej przedsiębiorstw uzdrowiskowych w Polsce, in: Turystyka uzdrowiskowa. Stan i perspektywy, ed. M. Boruszczak, Wyższa Szkoła Turystyki i Hotelarstwa, Gdańsk 2009, pp. 217-230.

${ }^{13}$ A. Rapacz, D.E. Jaremen, Empirical Analysis of Selected Attributes of Innovation in Karpacz Tourist Enterprises, "Management" 2011, Vol. 15, No. 2, pp. 256-270.

${ }^{14}$ E. Szymańska, Procesy innowacyjne przedsiębiorstw świadczacych ustugi $w$ zakresie organizacji imprez turystycznych, Oficyna Wydawnicza Politechniki Białostockiej, Białystok 2013. 
systems functioning in an external environment of an organization. A client occupies an important place in this system, since he/she is not only an innovation addressee or its source, but also an active participant of innovation processes occurring in a tourist enterprise.

The suggested model has certain limitations, among which the most important ones are as follows: no empirical verification of the established subsystems and relations, the selection of innovation model, the choice of an enterprise model. Nevertheless, the performed studies resulted in developing a theoretical background for analyzing an innovation system functioning in tourist enterprises in Poland.

\section{References}

Czerniak J., Polityka innowacyjna w Polsce, analiza i proponowane kierunki zmian, Difin, Warszawa 2013.

den Hertog P., Knowledge-Intensive Business Services as Co-producers of Innovation, "International Journal of Innovation Management" 2000, Vol. 4, No. 4.

Europejskie wymiary przedsiębiorczości, eds. H. Kruk, K. Skrzeszewska, Akademia Morska, Gdynia 2008.

Galar R., Gospodarka oparta na wiedzy i innowacje przełomowe, in: Gospodarka oparta na wiedzy-wyzwania dla Polski XXI wieku, ed. A. Kukliński, Warszawa 2001.

Gruszecki T., Wspótczesne teorie przedsiębiorstwa, Wydawnictwo Naukowe PWN, Warszawa 2002.

Howells J., Innovation and Services: New Conceptual Framework, CRIC Discussion Paper, No. 38, August 2000.

Innowacje w zrównoważonym rozwoju organizacji, ed. W. Janasz, Difin, Warszawa 2011.

Janasz W., Kozioł K., Determinanty działalności innowacyjnej przedsiębiorstw, PWE, Warszawa 2007.

Januszewska M., Nawrocka E., Rola klienta $w$ działalności innowacyjnej przedsiębiorstw uzdrowiskowych w Polsce, in: Turystyka uzdrowiskowa. Stan i perspektywy, ed. M. Boruszczak, Wyższa Szkoła Turystyki i Hotelarstwa, Gdańsk 2009.

Jasiński A.H., Ciborowski R., Ekonomika i zarzadzanie innowacjami, Wydawnictwo Uniwersytetu w Białymstoku, Białystok 2012.

Jasiński A.H., Innowacyjność w gospodarce Polski, modele, bariery, instrumenty wsparcia, Wydawnictwo Naukowe Wydziału Zarządzania Uniwersytetu Warszawskiego, Warszawa 2014.

Juchniewicz M., Grabowska B., Innowacyjność mikro-przedsiębiorstw w Polsce, PARP, Warszawa 2010.

Kołodziejczyk A., Ewolucja struktur organizacyjnych ku przestrzeni wirtualno-sieciowej, Prace Naukowe Uniwersytetu Ekonomicznego we Wrocławiu nr 275, Wrocław 2012.

Kulturowe kadrowe problemy internacjonalizacji przedsiębiorstw, ed. P. Wachowiak, SGH, Warszawa 2008.

Küpper C., Service Innovation - A Review of the State of the Art, Working Paper Series LMU, University of Munich, Institute for Innovation Research and Technology Management, Munich 2001.

Leich D.M., Gökduman S., Baaken T., Service Innovation, Project Report, University of Applied Sciences, Münster 2010, www.science-marketing.com.

Lewandowska M.S., Innowacje otwarte polskich przedsiębiorstw, „Gospodarka Narodowa” 2014, nr 2.

Penc J., Innowacje i zmiany w firmie, Agencja Wydawnicza Placet, Warszawa 1999.

Perechuda K., Nawrocka E., Zarządzanie informacja i wiedza jako instrument uzyskiwania przewagi konkurencyjnej podmiotów gospodarki turystycznej, Ekonomiczne Problemy Turystyki nr 7, Zeszyty Naukowe Uniwersytetu Szczecińskiego nr 429, Szczecin 2006.

Perenc J., Hołub-Iwan J., Innowacje w rozwoju konkurencyjności firm, Wydawnictwo C.H. Beck, Warszawa 2011.

Prahalad C.K., Ramaswamy V., Przyszłość konkurencji, PWE, Warszawa 2005.

Probst G., Raub S., Romhardt K., Zarządzanie wiedzą w organizacji, Oficyna Ekonomiczna, Kraków 2002.

Rapacz A., Jaremen D.E., Empirical Analysis of Selected Attributes of Innovation in Karpacz Tourist Enterprises, "Management" 2011, Vol. 15, No. 2. 
Słownik wyrazów obcych, ed. J. Tokarski, PWN, Warszawa 1980.

Szymańska E., Procesy innowacyjne przedsiębiorstw świadczacych usługi w zakresie organizacji imprez turystycznych, Oficyna Wydawnicza Politechniki Białostockiej, Białystok 2013.

Waresa S., Systemy innowacyjne we współczesnej gospodarce światowej, Wydawnictwo Naukowe PWN, Warszawa 2012.

\section{SYSTEM INNOWACJI PRZEDSIĘBIORSTWA TURYSTYCZNEGO - UJĘCIE MODELOWE}

\footnotetext{
SŁOWA KLUCZOWE model innowacji, przedsiębiorstwo turystyczne, system innowacji przedsiębiorstwa turystycznego

STRESZCZENIE

Celem artykułu jest podjęcie próby budowy modelu system innowacji przedsiębiorstwa turystycznego, pozwalającego wyjaśnić mechanizm działań innowacyjnych w turystyce. Podstawową metodą badawczą była analiza literatury. Modelowanie oparto na metodzie opisowej, której podstawą jest metoda dedukcji. Efektem procesu badawczego jest propozycja modelu systemu innowacji przedsiębiorstwa turystycznego (SIPT). Artykuł ma charakter przeglądowo-teoretyczny.
} 